\title{
Ice thickness, internal structure and subglacial topography of Bowles Plateau ice cap and the main ice divides of Livingston Island, Antarctica, by ground-based radio-echo sounding
}

\author{
Yu. Ya. MACHERET, ${ }^{1}$ J. OTERO ${ }^{2}$ F.J. NAVARRO, ${ }^{2}$ E.V. VASILENKO, ${ }^{3}$ M.I. CORCUERA, ${ }^{2}$ \\ M.L. CUADRADO, ${ }^{2}$ A.F. GLAZOVSKY ${ }^{1}$ \\ ${ }^{1}$ Institute of Geography, Russian Academy of Sciences, 29 Staromonetny Street, 109017 Moscow, Russia \\ ${ }^{2}$ Departamento Matemática Aplicada, ETSI de Telecomunicación, Universidad Politécnica de Madrid, \\ Avenida Complutense 30, ES-28040 Madrid, Spain \\ E-mail: fnv@mat.upm.es \\ ${ }^{3}$ Institute of Industrial Research Akadempribor, Academy of Sciences of Uzbekistan, Akademgorodok, \\ St. F. Hujaev 28, Tashkent 100125, Uzbekistan
}

\begin{abstract}
We present the results of low-frequency $(20 \mathrm{MHz})$ radio-echo sounding (RES) carried out in December 2000 and December 2006 on the main ice divides of Livingston Island, South Shetland Islands (SSI), Antarctica, and Bowles Plateau, Antarctica, respectively, as well as high-frequency $(200 \mathrm{MHz})$ RES on the latter, aimed at determining the ice thickness, internal structure and subglacial relief. Typical ice thickness along the main ice divides is $\sim 150 \mathrm{~m}$, reaching maxima of $\sim 200 \mathrm{~m}$. On Bowles Plateau the ice is much thicker, with an average of $265 \mathrm{~m}$ and maxima of $\sim 500 \mathrm{~m}$. The bed below the main ice divides is above sea level, while part of the outlet glaciers from Bowles Plateau lies significantly below sea level, down to $-\mathbf{1 2 0} \mathrm{m}$. The strong scattering of the radio waves in the areas under study constitutes further evidence that the ice in the accumulation area of the ice masses of the SSI is temperate. Typical thickness of the firn layer in Bowles Plateau is $20-35 \mathrm{~m}$, similar to that found in King George ice cap. A strong internal reflector within the firn layer, interpreted as a tephra layer from the 1970 eruption at Deception Island, has allowed a rough estimate of the specific mass balances for Bowles Plateau within 0.20-0.40 $\mathrm{m} \mathrm{a}^{-1}$ w.e., as average values for the period 1970-2006.
\end{abstract}

\section{INTRODUCTION}

The South Shetland Islands (SSI) are located at $\sim 115 \mathrm{~km}$ to the west of the northern tip of the Antarctic Peninsula and comprise 18 ice-covered islands, King George and Livingston Islands being the two largest (Fig. 1a). Ice-temperature measurements in shallow boreholes have indicated that the ice masses in the accumulation areas of these islands and neighbouring Nelson Island (Fig. 1a) are temperate (Orheim and Govorukha, 1982; Ren and others, 1995; Hun and Kang, 2002; Travassos and Simões, 2004), in contrast with the prevailing cold thermal regime of the ice masses further south in Antarctica. However, some evidence has been put forward concerning the polythermal structure of the ablation area of certain glaciers such as Hurd Glacier, Livingston Island (Molina and others, 2007). During the last 40 years the ice caps in King George and Livingston Islands have retreated by $6.6 \%$ and $4.3 \%$ in area, respectively, reflecting higher than average climate warming in this region (Simões and Bremer, 1995; Macheret and others, 1997a,b; Calvet and others, 1999; Macheret and Moskalevsky, 1999; Simões and others, 1999; Molina and others, 2007).

According to estimations by Vinogradov and Psareva (1990), based on analysis of large-scale (1:2 500 000) maps and available ice-thickness measurements, the total area of the archipelago is $3728 \mathrm{~km}^{2}$, the average ice thickness is $140 \mathrm{~m}$ and the total ice volume is $469.7 \mathrm{~km}^{3}$.

In the SSI, data on ice thickness have only been collected at Nelson Island (Ren and others, 1995), King George Island (Govorukha and others, 1974; Macheret and others, 1997a,b; Macheret and Moskalevsky, 1999; Hun and Kang,
2002; Travassos and Simões, 2004) and Livingston Island. At the latter location, until very recently the ice thickness was known only at four points in the northeastern part of the island from airborne radio-echo sounding (RES) performed in 1975 by the British Antarctic Survey at a frequency of $35 \mathrm{MHz}$ (personal communication from D. Vaughan, 1995), showing ice thickness between 200 and $400 \mathrm{~m}$. At Livingston Island, ice-thickness measurements by seismic refraction and reflection techniques were carried out on Johnsons Glacier, Hurd Peninsula, in the vicinity of the Spanish Antarctic station Juan Carlos I, in 1996/97 and 1997/98 (Benjumea and Teixidó, 2001; Benjumea and others, 2003; Navarro and others, 2005). Detailed icethickness measurements were also carried out at Johnsons and Hurd Glaciers by ground-based RES in 1999/2000, 2000/01, 2001/02, 2003/04 and 2004/05 (Benjumea and others, 2003; Navarro and others, 2005; Molina and others, 2007). Larger-scale ground-based RES measurements on Livingston Island were also performed in December 2000, along the main ice divides of the ice cap (Fig. 1b), and in December 2006 on the eastern part of the island, at Bowles ice plateau and two neighbouring outlet glaciers, Huron Glacier and an unnamed glacier north of Mount Bowles, both flowing eastwards (Fig. $1 \mathrm{~b}$ and c). In this paper, we present and discuss the RES data collected in these two latter areas, as well as related data on the radio-wave velocity in the glacier firn-ice sequence. These data are of interest in order to estimate the total ice volume stored in the SSI, and therefore its potential contribution to sea-level rise, as the Antarctic Peninsula area is known to be very sensitive to climate warming. 

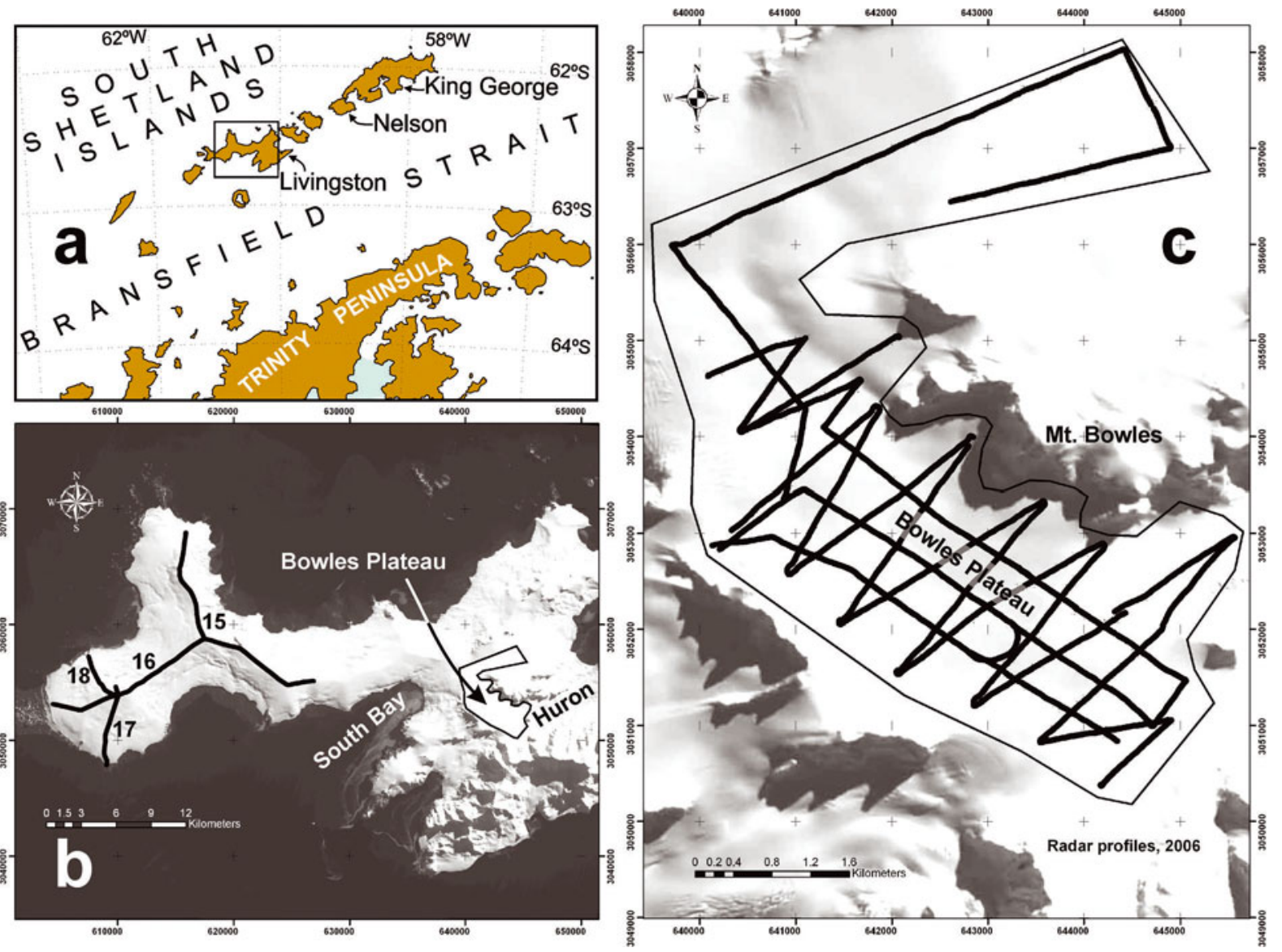

Fig. 1. (a) Location map for the South Shetland Islands, relative to Trinity Peninsula, Antarctic Peninsula, showing the location of King George, Nelson and Livingston islands. (b) Location of the radar profiles along the western ice divides of Livingston Island and Bowles Plateau, to the east, geo-referenced with respect to a Système Probatoire pour l'Observation de la Terre (SPOT) image taken in 2001. (c) Location of the low-frequency $(20 \mathrm{MHz})$ radar profiles done on Bowles Plateau.

\section{METHODS}

\section{Radar equipment and settings}

For radar measurements the following radar equipment was used: in 2000 the monopulse ice-penetrating radar VIRL-2 with a central frequency of $20 \mathrm{MHz}$ (Vasilenko and others, 2002), and in 2006 its modification, the radar VIRL-6 (Berikashvili and others, 2006), as well as a groundpenetrating radar Ramac/GPR with $200 \mathrm{MHz}$ antennae. VIRL-2 and VIRL- 6 were used to determine the ice thickness, while Ramac was mainly intended for studying the structure of the snow-firn sequence at Bowles ice plateau. In addition to radar data, navigation information from a global positioning system (GPS) was recorded for both VIRL and Ramac radars, storing the data in a dedicated digital recording system and a laptop, respectively. Two systems of transmitter-receiver synchronization were used: a radio link for VIRL-2 and an optic fibre link for VIRL-6 and Ramac. An odometer was also used to measure the distance along the radar profiles and for transmitter triggering.

VIRL-2 and VIRL-6 radars were installed on two Nansen sledges towed by a snowmobile, while Ramac radar was placed on a plastic pulka. The distance between the transmitting and receiving antennae of VIRL-2 and VIRL-6 was 9 and $11 \mathrm{~m}$, respectively, while for Ramac $200 \mathrm{MHz}$ it was set to $0.6 \mathrm{~m}$. The antennae were arranged collinearly and following the profile direction. Radar and GPS data were collected at 2-3 $\mathrm{m}$ distance between records for VIRL radars and $1 \mathrm{~m}$ for Ramac radar.

\section{Radar profiling}

In December 2000, RES measurements with VIRL-2 were performed along the main ice divides of the ice cap (Fig. 1b). The total length of radar profiles was $46.5 \mathrm{~km}$. More detailed RES measurements with VIRL-6 were carried out at the Bowles ice plateau in December 2006 (Fig. 1b and c). The total length of radar profiling was $101.5 \mathrm{~km}$. In order to calibrate the stand-alone GPS elevation data, measurements with a differential GPS (DGPS) receiver were also made at both end-points of every radar profile. In the northwestern and southeastern parts of Bowles Plateau, measurements with Ramac $200 \mathrm{MHz}$ radar were also made in December 2006 (Fig. 2). In fact, the latter profiling covered the same areas as those for the low-frequency radar (Fig. 1c); however, failures in the GPS receiver implied that only a fraction of the total profiles (those shown in Fig. 2) were properly georeferenced. The total length of geo-referenced Ramac radar profiles was $33 \mathrm{~km}$.

\section{Radio-wave velocity estimates}

Radar profiles of 2000 and 2006 correspond to accumulation areas. In order to calculate the thickness of the snow-firn layer and the total snow-firn-ice column thickness we need appropriate radio-wave velocity (RWV) estimates. We rely on several data sources for such estimates (most of them our own data), all of them obtained from Johnsons and Hurd Glaciers, not far from Bowles Plateau. These consist of: 

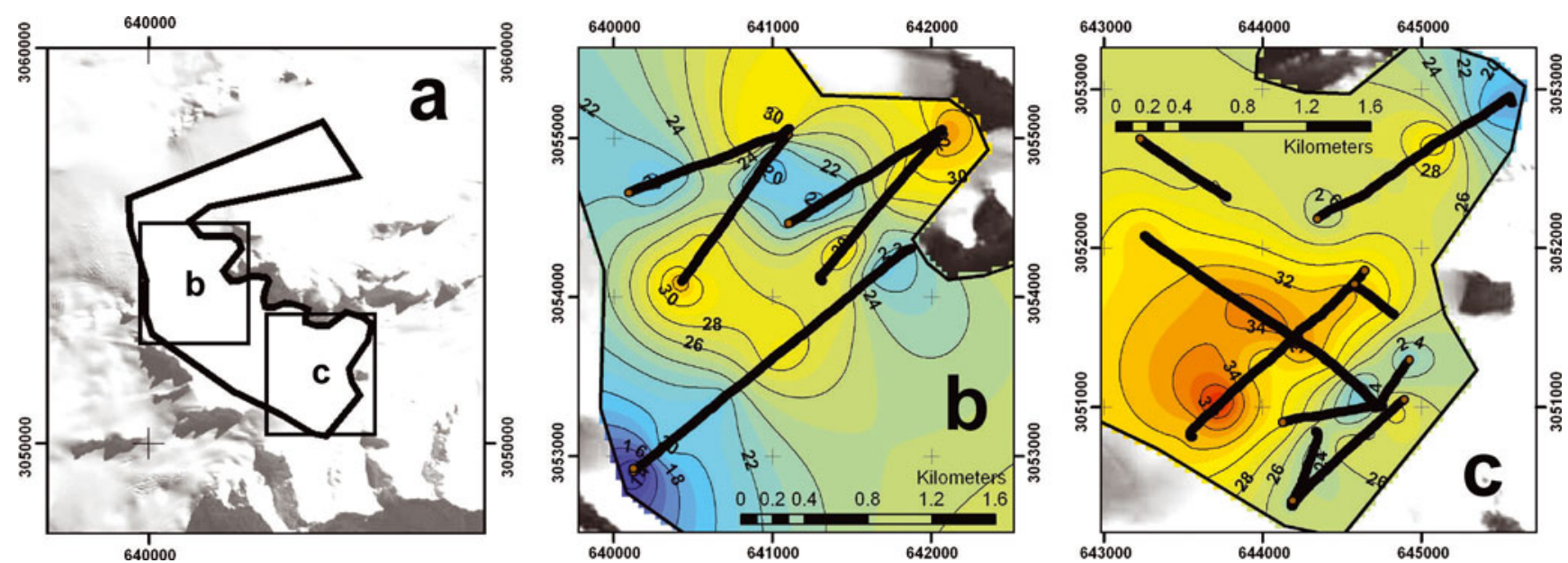

Fig. 2. (a) Location of the high-frequency $(200 \mathrm{MHz})$ radar profiles done on the northwestern and southeastern parts of Bowles Plateau. (b, c) Layout of the profiles, together with the corresponding firn-layer thickness maps.

1. RWV estimates from VIRL-2 radar diffraction hyperbolae measured in 1999/2000 and reported in Benjumea and others (2003), which provide the average RWV for the ice column above the diffractor bodies.

2. RWV estimates from common-midpoint (CMP) measurements with VIRL-2A radar $(20 \mathrm{MHz})$ made in 2003/04, which provide the average RWV for the full ice column from bed to surface (e.g. Macheret and others, 1993; Macheret, 2006). Results for Hurd Glacier were reported by Lapazaran (2004), while those for Johnsons Glacier, hitherto unpublished, are reported in this paper.

3. RWV estimates for the snow-firn layer from CMP measurements made with $200 \mathrm{MHz}$ Ramac radar in 2003/04, hitherto unpublished and reported in this paper.

4. RWV for the snow-firn layer estimated from the density measurements at an intermediate (37 m deep) ice core, using the relationship between RWV and ice density by Macheret and Glazovsky (2000). The density values correspond to the deepest of a set of three intermediate ice cores drilled by M. Pourchet and J.M. Casas in 1999/ 2000 (Pourchet and Casas, unpublished data).

\section{Radar data processing}

Radar data processing was carried out using RadExPro software from GDS Production (Kulnitsky and others, 2000). The following modules were used: Amplitude Correction, Bandpass Filtering, Antenna Ringdown Removal, Apply Statics, Picking, FK Stolt Migration (FK-SM) and Interactive Velocity Analysis (IVA). The FK-SM procedure was used only for VIRL-2 and VIRL-6 data collected along straight-line profiles, and the IVA module was used for interpretation of CMP data.

\section{Construction of surface elevation map for Bowles ice plateau}

Ice surface elevation data for most of Livingston Island (except Hurd Peninsula) are only available from the $1: 200000$ British (United Kingdom: DOS, 1968) and $1: 100000$ Spanish (SGE, 1997) maps based on 1956 British Antarctic Survey aerial photograph series and are therefore outdated (e.g. ice-thickness decreases up to $40 \mathrm{~m}$ have been reported for some areas of Hurd Peninsula ice cap during the period 1956-2000, though the average thickness change has been of only $-5.5 \pm 4.4 \mathrm{~m}$; Molina and others, 2007). In order to construct a map of the present glacier surface elevation for Bowles ice plateau, we used elevation data $Z_{\mathrm{GPS}}$ measured at every radar trace location by a stand-alone GPS, corrected by elevation data $Z_{\text {DGPS }}$ measured by DGPS at the end-points of all VIRL- 6 radar profiles. The relationship between GPS and DGPS elevations measured at these control points showed a good linear correlation $\left(r^{2}=0.9904\right.$; see Fig. 3$)$, described by the equation

$$
Z_{\mathrm{DGPS}}=1.0002 Z_{\mathrm{GPS}}-5.2476
$$

which was used to calculate corrected surface GPS elevations and to construct a surface elevation map for Bowles Plateau.

The bedrock elevation map was constructed by subtracting from the surface elevation map the ice-thickness map obtained from the radar data.

\section{RESULTS}

\section{Radio-wave velocity estimates}

We reported in an earlier paper (Benjumea and others, 2003), for Johnsons and Hurd Glaciers, an average RWV of $164.9 \pm 4.2 \mathrm{~m} \mathrm{us}^{-1}$ measured from 42 radar diffraction hyperbolae corresponding to diffractor bodies at depths of 28-162 $\mathrm{m}$. These results are consistent with those obtained for the full ice column from our CMP measurements in 2003/04. For Hurd Glacier, typical values were $165.3 \mathrm{~m} \mathrm{\mu s}^{-1}$ for the ablation area and $168.0 \mathrm{~m} \mathrm{\mu s}^{-1}$ for the accumulation area, as reported by Lapazaran (2004), though in one case an unusually high value was obtained $\left(176.4 \mathrm{~m} \mathrm{\mu s}^{-1}\right)$, which is attributed to the presence of air within the water drainage system. At Johnsons Glacier, values in the range 160.1-166.1 $\mathrm{m} \mathrm{\mu s}^{-1}$ were found at three locations. An unusually high value of $187.9 \mathrm{~m} \mathrm{ss}^{-1}$ was also found, but this corresponded to a location at the accumulation area having low ice thickness, $\sim 70 \mathrm{~m}$, of which $\sim 20 \mathrm{~m}$ correspond to the snow-firn layer, thus resulting in a high RWV because of the much higher RWV in snow-firn $\left(195 \mathrm{~m} \mathrm{ss}^{-1}\right.$ as layer average for this area, as shown below).

Taking into account the above data, we used for the timeto-depth conversion of the radar data from Bowles Plateau 


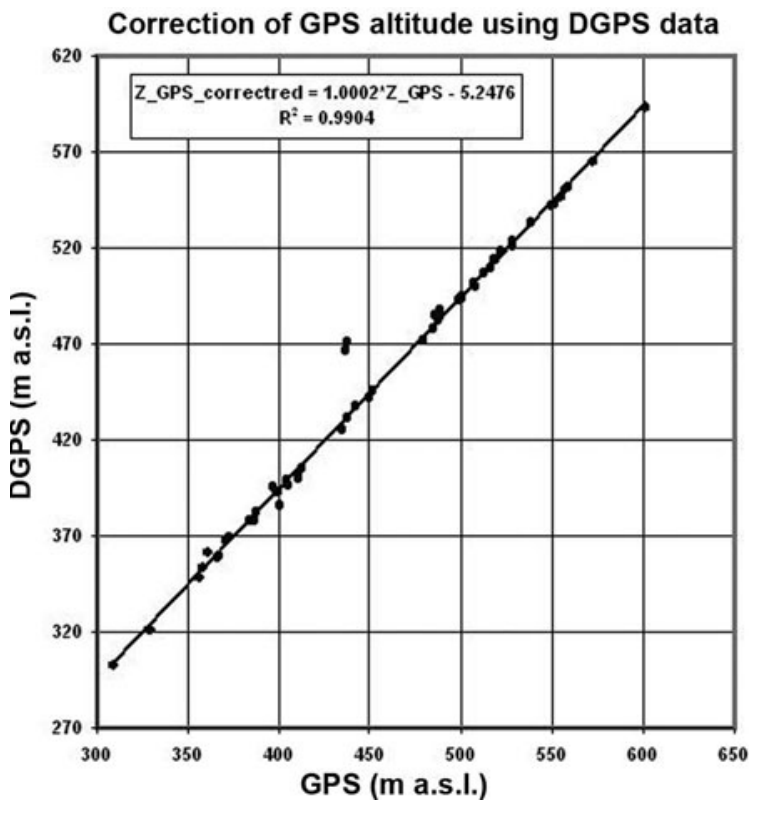

Fig. 3. Altitude of radar profile end-points (Bowles area) measured by differential GPS versus same variable as measured by standalone GPS, and linear fit of the data.

and the main ice divides of Livingston Island a value of $165 \mathrm{~m} \mathrm{\mu s}^{-1}$, taking into account the temperate nature of the ice in these areas and that the firn layer represents, for Bowles Plateau (where most of the radar records were collected), a relatively small fraction of the full firn-ice column (as compared to other locations in Livingston Island).

Regarding the RWV for the snow-firn layer, we have estimates from two independent data sources, giving equivalent results. For two of the three $200 \mathrm{MHz}$ CMP measurements made in December 2003 on the ice divide between Johnsons and Hurd Glaciers, we obtained velocities of 188.3

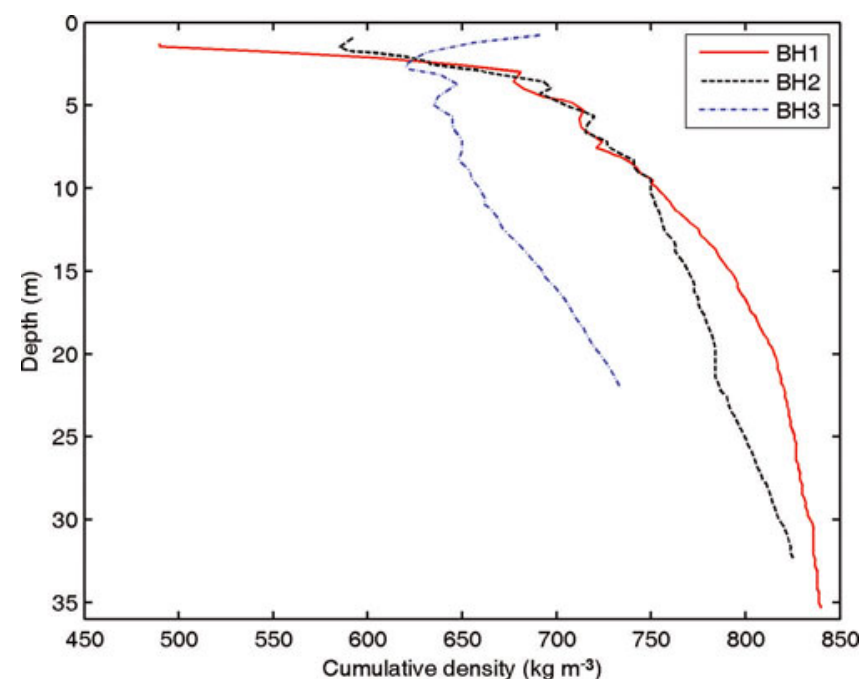

Fig. 4. Cumulative density curves for the three shallow-intermediate-depth ice cores drilled in 1999/2000 at three locations of Johnsons Glacier (data courtesy of M. Pourchet and J.M. Casas). $\mathrm{BH} 1$ corresponds to the highest point of the ice divide between Johnsons and Hurd Glaciers and was used to estimate the RWV for the firn layer. The different shape of the $\mathrm{BH} 3$ curve is attributed to the higher accumulation rate at this location due to the orography and the prevailing wind direction.

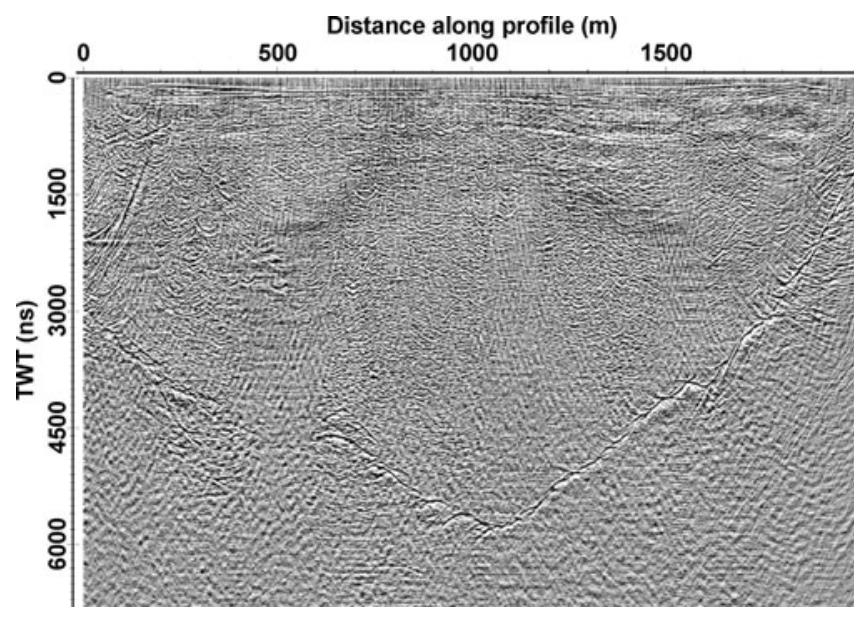

Fig. 5. Sample of radargram obtained with VIRL-6 radar $(20 \mathrm{MHz})$ on a cross-profile of Bowles Plateau. The vertical scale is shown as two-way travel time (TWT). The thickest ice shown is $\sim 508 \mathrm{~m}$, considering a RWV of $0.165 \mathrm{~m} \mathrm{~ns}^{-1}$.

and $191.5 \mathrm{~m} \mathrm{ss}^{-1}$ as snow-firn column average velocities above 20.0 and $23.4 \mathrm{~m}$ depth, respectively, averaging $189.9 \mathrm{~m} \mathrm{ss}^{-1}$. We do not use the third measurement, for which a RWV of $198.1 \mathrm{~m} \mathrm{ss}^{-1}$ was obtained, because this corresponded to a reflector located at only $12.9 \mathrm{~m}$ depth, while the firn thickness in this area is $\sim 20 \mathrm{~m}$ (Furdada and others, 1999). This RWV for the snow-firn sequence agrees with that of $190 \mathrm{~m} \mathrm{\mu s}^{-1}$ obtained by applying the Macheret and Glazovsky (2000) relationship between density and velocity to the density data for the deepest ice core $(\mathrm{BH} 1)$ of those shown in Figure 4, also located at the ice divide between Johnsons and Hurd Glaciers. It also agrees with the $190 \mathrm{~m} \mathrm{\mu s}^{-1}$ RWV obtained by Travassos and Simões (2004) in the accumulation area of King George ice cap from CMP measurements with a pulseEKKO IV $50 \mathrm{MHz}$ radar. Consequently, we took for the time-to-depth conversion of the $200 \mathrm{MHz}$ radar data from Bowles Plateau for the firn layer a RWV of $190 \mathrm{~m} \mathrm{ss}^{-1}$.

\section{Ice-thickness, glacier surface and bedrock elevation maps}

Well-defined bedrock reflections were recorded with VIRL-2 and VIRL-6 at both the ice-cap divides and Bowles ice plateau. A sample for the latter is shown in Figure 5. Notice the strong internal scattering, typical of temperate ice below a firn layer.

The results of ice-thickness measurements at the main ice divides of Livingston ice cap are presented in Figure 6 (see location of profiles in Fig. 1b). The maximum ice thickness along profile 15, which corresponds to the main ice divide, reaches $200 \mathrm{~m}$ and indicates a quite complicated sub-ice relief with deep hollows and high peaks with elevations up to $300 \mathrm{~m}$ a.s.l. (Fig. 6a). At profiles 16-18 the ice thickness is generally smaller, typically $\sim 150 \mathrm{~m}$ (Fig. $6 \mathrm{~b}-\mathrm{d}$ ). Notice that at all profiles shown for the ice divides, bedrock is above sea level. At Bowles ice plateau the ice thickness is much larger, reaching values of $\sim 500 \mathrm{~m}$, as shown in the sample radargram of Figure 5. The ice-thickness map for the entire Bowles area is shown in Figure 7a; the greatest thickness is reached in the central area of Bowles Plateau, though quite high values are also reached in the northeastern area shown in the figure, corresponding to the unnamed glacier flowing 


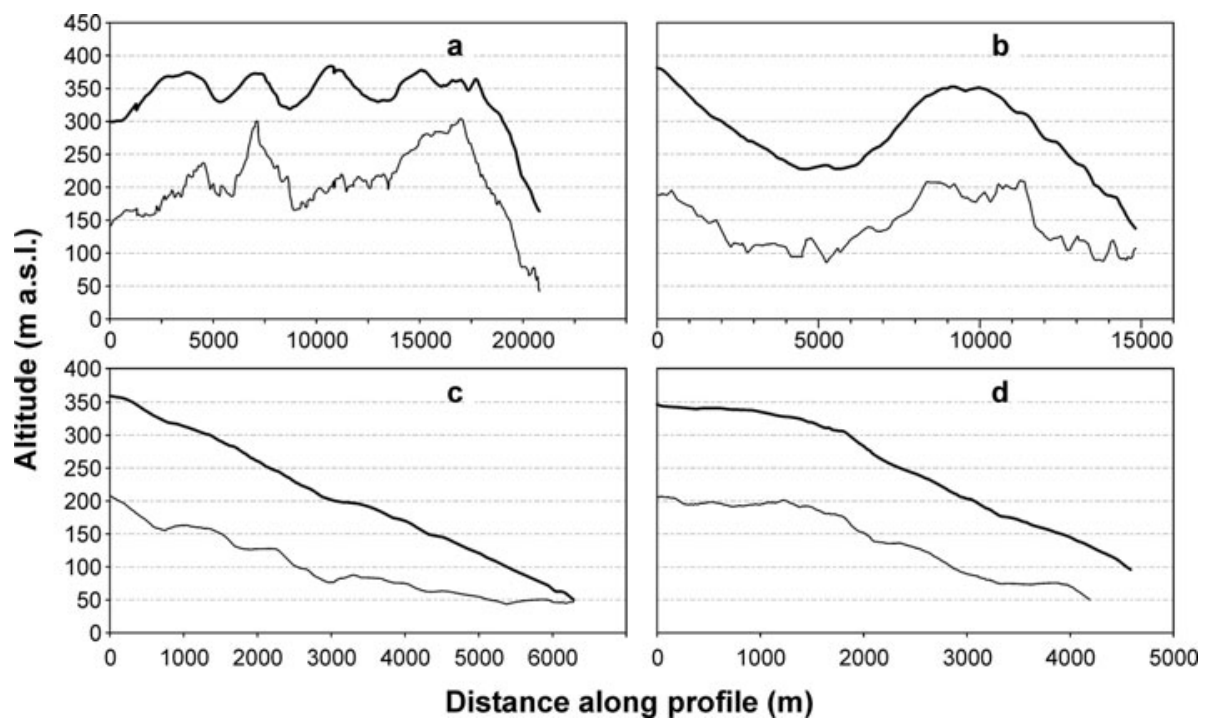

Fig. 6. Ice-surface (thick line) and glacier bed (thin line) elevations along VIRL-2 radar profiles 15 (a), 16 (b), 17 (c) and 18 (d) shown in Figure 1b, corresponding to the main ice divides of the western part of Livingston Island. Profiles 15 and 16 are part of the main ice divide, while profiles 17 and 18 are side ice divides.

eastwards. The surface elevation map constructed for Bowles ice plateau from the corrected surface GPS elevations is presented in Figure $7 \mathrm{~b}$. It shows smooth surface slopes, except for the head of Huron Glacier, in the easternmost part of the figure. The bedrock elevation map obtained by subtracting the ice thickness from the ice surface can be seen in Figure 7c. Notice that the bedrock is below sea level at a large fraction of the central to northwestern part of Bowles Plateau, and that values below $-120 \mathrm{~m}$ are reached in the large depression to the northwest. Values below sea level are also reached to the northeast.

The glacier area under study in the Bowles Plateau region, and its total ice volume, were computed using ESRI ArcMap software, giving $21.8 \mathrm{~km}^{2}$ and $6.2 \mathrm{~km}^{3}$, respectively, and an average ice thickness of $265 \mathrm{~m}$.

\section{Structure of the snow-firn sequence}

Well-defined reflections from the firn-ice interface were recorded with Ramac $200 \mathrm{MHz}$ radar in the northwestern and southeastern parts of Bowles Plateau (Fig. 2). A sample radargram is shown in Figure 8. Two clearly differentiated areas are apparent: the higher area, with sub-horizontal layering, which corresponds to the firn layer, and the lower area, corresponding to the ice below the firn layer, which shows the strong scattering (diffractions) typical of temperate ice, leading us to interpret the reflector at 25-30 m depth as the firn-ice interface. This is a typical firn layer thickness for the area, as shown in Figure $2 \mathrm{a}$ and $\mathrm{b}$, where the maximum firn layer thickness is $\sim 36 \mathrm{~m}$. It is also consistent with the thickness of $\sim 30 \mathrm{~m}$ found by Travassos and Simões (2004), from radar data, in the accumulation area of Lange Glacier and Collins ice cap, King George Island. In Figure 8 one can clearly see, within the firn layer, another quite marked internal reflector at $\sim 15 \mathrm{~m}$ depth. This layer was visible at a similar depth (though with variations within 10-20 m depth) in many profiles; however, several layers of similar reflectivity were found in some profiles, making it difficult to interpret which one corresponded to the internal layer visible within the firn layer in Figure 8, so that our attempts to map the thickness of the layer above this reflector were not successful (the resulting map was not 'credible' in some areas).

\section{DISCUSSION}

1. Previous data on ice thickness in the SSI are quite limited. Ice-thickness measurements have only been made on 3 of 18 glacierized islands: King George, Nelson and Livingston Islands. On King George Island the radar measurements were performed along the main ice divide, with a total profile length of $110 \mathrm{~km}$. More detailed measurements were made in the upper part of Lange outlet glacier (Macheret and others, 1997a,b; Macheret and Moskalevsky, 1999). The maximum measured ice thickness on King George Island was $330 \mathrm{~m}$, i.e. larger than that measured along the main ice divide of Livingston Island ( 200 m) but smaller than that measured on Bowles Plateau ( $\sim 500 \mathrm{~m})$. On the smaller Nelson Island, RES measurements showed a maximum ice thickness of $260 \mathrm{~m}$ (Ren and others, 1995). Focusing on Livingston Island, the thickest ice $(\sim 500 \mathrm{~m})$ is found in the central part of Bowles Plateau, and maximum ice thickness at the northeastern part of the unnamed outlet glacier flowing to the east approaches $400 \mathrm{~m}$ (see northeasternmost part of Fig. 7a). On Livingston Island, RES measurements have also been made on the ice cap covering Hurd Peninsula, which is divided into two main glacier units, the tidewater Johnsons Glacier and the land-terminating Hurd Glacier (Benjumea and others, 2003; Navarro and others, 2005; Molina and others, 2007). The maximum measured ice thicknesses are 196 and $205 \mathrm{~m}$, respectively, and the average ice thickness for the full Hurd Peninsula ice cap is $94 \mathrm{~m}$, while that for the area under study in Bowles Plateau and the heads of the two outlet glaciers flowing to the east is $265 \mathrm{~m}$. All of these values lie in a thickness range consistent with the average thickness estimated by Vinogradov and Psareva (1990) for the whole of the SSI (140 m). Our ice-volume estimate for the Bowles Plateau area is $6.2 \mathrm{~km}^{3}$, which 

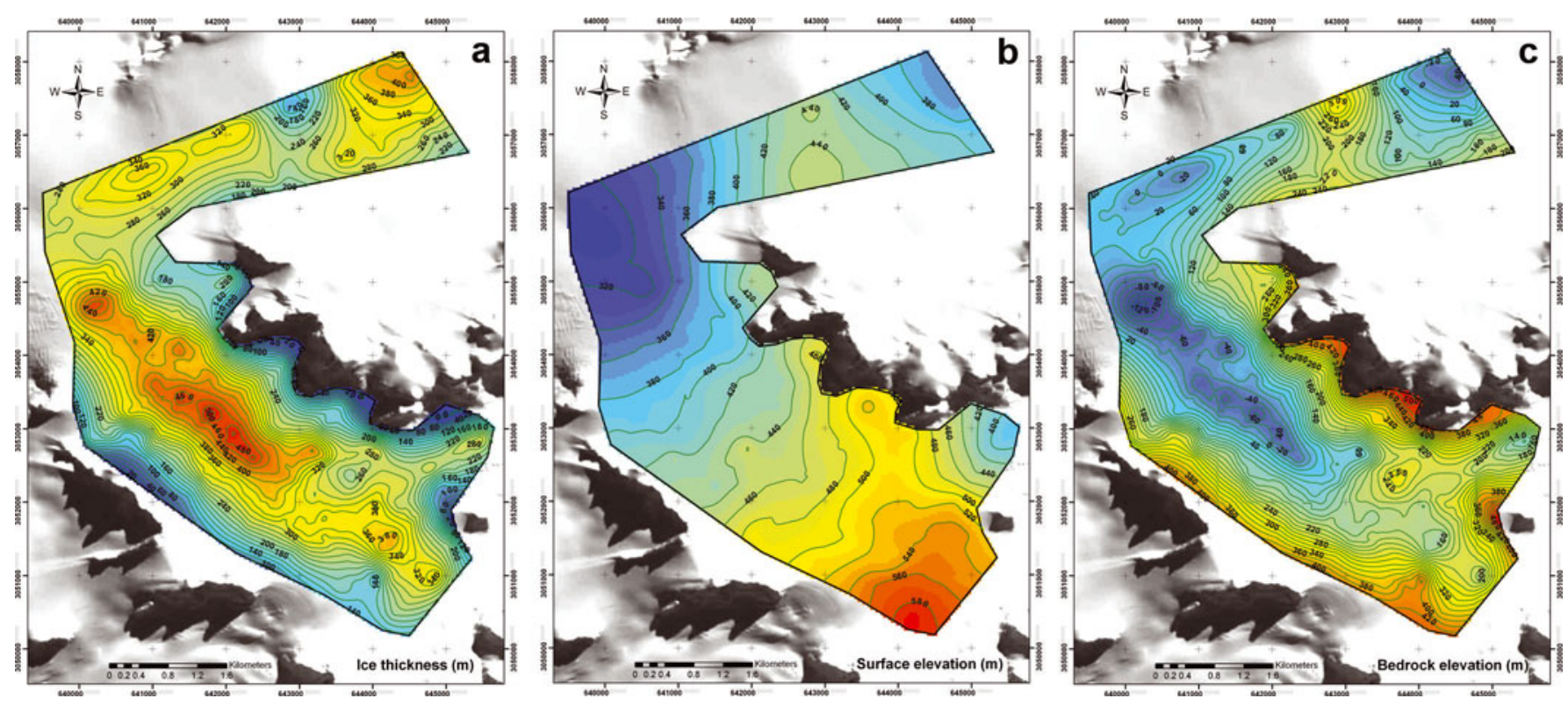

Fig. 7. Ice-thickness (a), ice-surface (b) and glacier bedrock (c) maps for Bowles Plateau and heads of outlet glaciers to the east, constructed from radar and corrected GPS data.

represents $1.3 \%$ of the total ice volume on the SSI, according to the estimate by Vinogradov and Psaryeva.

2. The RES measurements reveal that the glacier bed topography along the main ice divides of Livingston Island is quite irregular and in a large scale follows the glacier surface topography (Fig. 6a and b), as happens in the main ice divides of King George ice cap (Macheret and others, 1997a,b; Macheret and Moskalevsky, 1999), whereas along the side ice divides of Livingston Island it is smoother (Fig. 6c and d). Among the outlet glaciers studied on these islands (Lange Glacier, King George Island; outlet glaciers from Bowles Plateau and Johnsons Glacier, Hurd Peninsula, Livingston Island), only in the glacier flowing to the west from the northern part of Bowles Plateau, and the unnamed glacier to the northeast, did we find large areas of bedrock lying significantly below sea level (down to $-120 \mathrm{~m}$ in the former case, as shown in Fig. 7c; notice, looking at Fig. 1b and

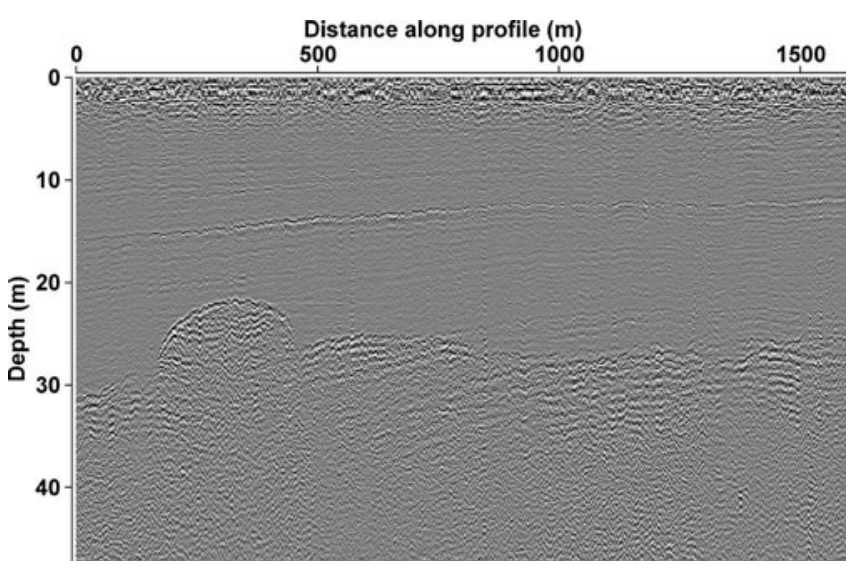

Fig. 8. Sample of radargram obtained with Ramac $200 \mathrm{MHz}$ radar on Bowles Plateau. The vertical scale is shown in metres, considering a firn-layer RWV of $0.190 \mathrm{~m} \mathrm{~ns}^{-1}$ for the time-to-depth conversion. the surface slopes shown in Fig. 7b, that the ice in the thickest part of Bowles Plateau flows westwards, ending in South Bay). This means that further climate warming in this region can lead to significant ice-volume reduction in the Bowles Plateau area.

3. The radar records collected at Livingston Island, both at the main ice divides of the ice cap and at Bowles ice plateau, using VIRL-2 and VIRL-6 monopulse radars operating at a central frequency of $20 \mathrm{MHz}$, show strong scattering of the radio waves, as can be appreciated in Figure 5. Marked scattering is also visible in the radar records collected at $200 \mathrm{MHz}$, in this case within the ice below the firn layer, as can be seen in Figure 8. Such scattering is typical of water inclusions in ice and can be interpreted as further evidence that the ice in the accumulation area of the ice masses of the SSI is temperate. However, we should remember that some evidence has been presented concerning the presence of a cold ice layer next to the surface in the ablation area of certain glaciers, such as Hurd Glacier in Livingston Island, being indicative of a polythermal structure (Molina and others, 2007).

4. In Bowles Plateau, the $200 \mathrm{MHz}$ radar records clearly show a firn layer, with internal stratification (Fig. 8) and typical thickness 20-35 m (Fig. 2), overlying an ice layer presenting large diffractions. These characteristics are similar to those described by Travassos and Simões (2004) for data collected in the accumulation area of King George ice cap using a pulseEKKO IV radar with $50 \mathrm{MHz}$ antennae. By comparing their radar records with density measurements in a neighbouring $49.7 \mathrm{~m}$ deep borehole, these authors interpreted the radar layering in the firn layer as being due to density changes in layers whose thickness has to lie within a certain range dependent on the radar wavelength and signal-to-noise ratio in order to be detectable. At the borehole location, they found the firn-ice transition at depths of about $37 \mathrm{~m}$ (from borehole data) and $33 \mathrm{~m}$ (from the closest radar 
profile, 2-3 km apart). The ice-core data suggest that this interface corresponds to the top of a layer $\sim 1 \mathrm{~m}$ thick consisting of water within a coarse grain firn. In most areas, their radar data showed the firn-ice transition at $\sim 30 \mathrm{~m}$ depth. Below the firn-ice interface, they interpreted large diffractions as indicative of highly inhomogeneous ice, probably due to pockets of water. Within the firn layer they also observed noise in the form of a crisscrossing pattern, attributed to the interference of closely spaced diffractions from water-filled voids and debris inclusions, but these diffractions were much smaller and weaker than those from below the firn-ice interface. Most of these features are consistent with our radar data from Bowles Plateau.

5. Within the firn layer, a strong internal reflector (see Fig. 8) is consistently found in most $200 \mathrm{MHz}$ radar profiles at a typical depth of $\sim 15 \mathrm{~m}$ but lying at depths of $10-20 \mathrm{~m}$. Looking for a possible explanation of this reflector, we have analysed the shallow ice-core data by Furdada and others (1999), collected at Johnsons and Hurd Glaciers in 1994/95, aimed at identifying both the ${ }^{137}$ Cs 1965 layer stemming from thermonuclear tests and the 1970 tephra layer stemming from the eruption at neighbouring Deception Island (Baker and McReath, 1971), in order to estimate the average mass balance for the periods 1965-93 and 1970-93, respectively. Tephrochronology has been successfully used at Livingston Island (Pallàs and others, 2001) and other South Shetland Island locations (e.g. Nelson Island (Qin and others, 1994)) for relative dating purposes and long-term average mass-balance estimate. In spite of the time-span between them, Furdada and others (1999) usually found the 1970 tephra layer associated with the ${ }^{137}$ Cs 1965 layer. In the borehole drilled at the summit of the ice divide between Johnsons and Hurd Glaciers, they found the latter at $10.22 \mathrm{~m}$ depth. From the cumulative density of the snow-firn column above, they estimated an average specific mass balance of $0.22 \mathrm{ma}^{-1}$ w.e. for the period 1965-93. We therefore hypothesize that the internal reflector at $\sim 15 \mathrm{~m}$ depth could correspond to the 1970 tephra layer (notice that Furdada and others found such a layer at $10.22 \mathrm{~m}$ depth, but 12 years before our radar sounding). The radar reflection from tephra layers is not directly associated with the presence of the tephra particles themselves but with the associated change in acidity levels (Fujita and Mae, 1994). Should this hypothesis be correct, considering the depth range of the internal reflector and assuming a range of cumulative densities between 650 and $750 \mathrm{~kg} \mathrm{~m}^{-3}$, average specific mass balances roughly within $0.20-0.40 \mathrm{~m} \mathrm{a}^{-1}$ w.e. result for Bowles Plateau during the period 1970-2006. This compares well with the $0.22 \mathrm{~m} \mathrm{a}^{-1}$ w.e. obtained for the Johnsons-Hurd divide summit, considering that this relatively low value was attributed to the partial removal of snow by wind at the Johnsons-Hurd divide summit (Ximenis, 2001), while the much smoother surface topography of Bowles Plateau would favour larger positive values of net mass balance. Although the cumulative densities presented in Figure 4 are even higher (except for $\mathrm{BH} 3$ ) than those mentioned above, they correspond to elevations lower (200-330 ma.s.I.) than those found in Bowles Plateau (300-600 ma.s.I.), showing positive temperatures during part of the summer and many episodes of surface melting, percolation of meltwater and refreezing, so that the firn layer has plenty of ice layers and lenses, and correspondingly high densities; in fact, at these elevations in Johnsons and Hurd Glaciers the firn-ice transition is typically reached at $\sim 20 \mathrm{~m}$ depth (e.g. Furdada and others, 1999).

\section{CONCLUSIONS}

We summarize the main conclusions from the above discussion as follows:

1. Typical ice thickness along the main ice divides of Livingston Island is $\sim 150 \mathrm{~m}$, reaching maxima of $\sim 200 \mathrm{~m}$. In Bowles Plateau and surrounding areas, the ice is much thicker, with an average of $265 \mathrm{~m}$ and maxima of $\sim 500 \mathrm{~m}$. In Hurd Peninsula, average thickness is $\sim 100 \mathrm{~m}$, with maximum values $\sim 200 \mathrm{~m}$. All of these values lie in a thickness range consistent with the average thickness estimated by Vinogradov and Psareva (1990) for the whole of the SSI $(140 \mathrm{~m})$. We estimate an ice volume for the Bowles Plateau area of $6.2 \mathrm{~km}^{3}$, which represents $1.3 \%$ of the total ice volume on the SSI, according to the estimate by Vinogradov and Psaryeva.

2. Among the outlet glaciers studied so far at the SSI, only those from Bowles Plateau lie significantly below sea level (down to $-120 \mathrm{~m}$, in extreme cases), which makes them especially sensitive to climate warming.

3. The strong scattering of the radio waves by the ice in the areas under study (all of them in the accumulation area) constitutes further evidence that the ice in the accumulation area of the ice masses of the SSI is temperate, though a polythermal structure has been suggested for the ablation area of some glaciers (Molina and others, 2007).

4. The typical thickness of the firn layer in Bowles Plateau is 20-35 m, similar to that found by Travassos and Simões (2004) for the accumulation area of King George ice cap.

5. Within the firn layer, a strong internal reflector is consistently found in most high-frequency radar profiles at 10-20 m depth. If, as we hypothesize, this reflector corresponds to the tephra layer from the 1970 eruption at neighbouring Deception Island, this would imply average net mass balances of $0.20-0.40 \mathrm{~m} \mathrm{a}^{-1}$ w.e. for Bowles Plateau during the period 1970-2006, which is consistent with the $0.22 \mathrm{~m} \mathrm{a}^{-1}$ w.e. estimated for Johnsons-Hurd divide summit by Furdada and others (1999) for the period 1965-93, considering the differences in geographical setting and climatic conditions at both locations.

\section{ACKNOWLEDGEMENTS}

This research was supported by grants CGL2005-05483 from the Spanish Ministry of Education and Science and Program 14, Branch of Earth Sciences of the Russian Academy of Sciences. We thank the scientific editor, R. Hindmarsh, and an anonymous reviewer for their suggestions to improve the manuscript. 


\section{REFERENCES}

Baker, P.E. and I. McReath. 1971. 1970 volcanic eruption at Deception Island. Nature (Phys. Sci.), 231(18), 5-9.

Benjumea, B. and T. Teixidó. 2001. Seismic reflection constraints on the glacial dynamics of Johnsons Glacier, Antarctica. J. Appl. Geophys., 46(1), 31-44.

Benjumea, B., Yu.Ya. Macheret, F.J. Navarro and T. Teixidó. 2003. Estimation of water content in a temperate glacier from radar and seismic sounding data. Ann. Glaciol., 37, 317-324.

Berirkashvili, V.Sh., E.V. Vasilenko, Yu.Ya. Macheret and V.G. Sokolov. 2006. Ul'sny radar dlya zondirovaniya lednikov s opticheskim kanalom sinkhronizatsii i tifrovoy brabotkoy signalov [Monopulse radar for sounding of glaciers with optical synchronization channel and digital processing of signals]. Radiotekhnika, 9, 52-57. [In Russian.]

Calvet, J., D. García-Sellés and J. Corbera. 1999. Fluctuaciones de la extensión del casquete glacial de la Isla Livingston (Shetland del Sur) desde 1956 hasta 1996. Acta Geol. Hispán., 34(4), 365-374.

Fujita, S. and S. Mae. 1994. Causes and nature of ice-sheet radioecho internal reflections estimated from the dielectric properties of ice. Ann. Glaciol., 20, 80-86

Furdada, G., M. Pourchet and J.M. Vilaplana. 1999. Characterization of Johnsons Glacier (Livingston Island, Antarctica) by means of shallow ice cores and their tephra and ${ }^{137} \mathrm{Cs}$ contents. Acta Geol. Hispán., 34(4), 391-401.

Govorukha, L.S., V.I. Chudakov and A.V. Shalygin. 1974. Radiolokatsionnoye zondirovaniye lednikovogo pokrova o. KingDzhordzh (Waterloo) [Radio-echo sounding of King George Island (Waterloo) ice cap]. Inf. Byull. Sov. Antarkt. Eksped. 89, 15-18. [In Russian with English summary.]

Hun, J. and J. Kang 2002. Glaciological study of Collins Ice Cap, King George Island, Antarctica. Lanzhou, Gansu Science and Technology Press.

Kulnitsky, L.M., P.A. Gofman and M.Y. Tokarev. 2000. Matematicheskaya obrabotka dannykh georadiolokatsii i systema RADEXPRO [Mathematical processing of georadar data and RADEXPRO system]. Razv. Okhrana Nedr, 3, 6-11. [In Russian.]

Lapazaran, J.J. 2004. Técnicas de procesado de datos de georradar y su aplicación al estudio del régimen termodinámico de los glaciares fríos y politérmicos. (PhD thesis, Universidad Politécnica de Madrid.)

Macheret, Yu.Ya. 2006. Radiosondirovanie lednikov [Radio-echo sounding of glaciers]. Moscow, Nauchny Mir. [In Russian.]

Macheret, Yu.Ya. and A.F. Glazovsky. 2000. Estimation of absolute water content in Spitsbergen glaciers from radar sounding data. Polar Res., 19(2), 205-216.

Macheret, Yu.Ya. and M.Yu. Moskalevsky. 1999a. Stroyeniye i dinamika vyvodnogo lednika Lendzh, lednikovoy kupol ostrova King-Dzhordzh, Yuzhnyye Shetlandskiye ostrova, Antarktida [Structure and dynamics of outlet tidewater Lange Glacier, King George Island ice cap, South Shetland Islands, Antarctica]. Antarktika, 34, 118-129. [In Russian with English summary.]

Macheret, Yu.Ya. and M.Yu. Moskalevsky. 1999b. Study of Lange Glacier on King George Island, Antarctica. Ann. Glaciol., 29, 202-206.

Macheret, Yu.Ya., M.Yu. Moskalevsky and E.V. Vasilenko. 1993. Velocity of radio waves in glaciers as an indicator of their hydrothermal state, structure and regime. J. Glaciol., 39(132), 373-384.

Macheret, Yu.Ya., M.Yu. Moskalevsky, J.C. Simões and L. Ladouch. 1997a. Radio echo-sounding of King George Island ice cap, South Shetland Islands, Antarctica. Mater. Glyatsiol. Issled./Data Glaciol. Stud. 83, 121-128.

Macheret, Yu.Ya., M.Yu. Moskalevsky, J.C. Simões and L. Ladouch. 1997b. Study of King George Island ice cap, South Shetland Islands, Antarctica using radio-echo sounding and SPOT and ERS1 SAR satellite images. In Proceedings of an International Seminar on the Use and Applications of ERS in Latin America, 25-30 November 1996, Viña del Mar, Chile. Noordwijk, European Space Agency, 249-256. (ESA Special Publication SP-45.)

Molina, C., F.J. Navarro, J. Calver, D. García-Sellés and J.J. Lapazaran. 2007. Hurd Peninsula glaciers, Livingston Island, Antarctica, as indicators of regional warming: ice-volume changes during the period 1956-2000. Ann. Glaciol., 46, 43-49.

Navarro, F.J., Yu.Ya. Macheret and B. Benjumea. 2005. Application of radar and seismic methods for the investigation of temperate glaciers. J. Appl. Geophys., 57(3), 193-211.

Orheim, O. and L.S. Govorukha. 1982. Present-day glaciation in the South Shetland Islands. Ann. Glaciol., 3, 233-238.

Pallàs, R., J.L. Smellie, J.M. Casas and J. Calvet. 2001. Using tephrochronology to date temperate ice: correlation between ice tephras on Livingston Island and eruptive units on Deception Island volcano (South Shetland Islands, Antarctica). Holocene, 11(2), 149-160.

Qin, D., G.A. Zielinski, M.S. Germani, J. Ren, X.X. Wang and W.T. Wang. 1994. Use of tephrochronology in the evaluation of accumulation rates on Nelson Ice Cap, South Shetland Islands, Antarctica. Sci. China B, 37(10), 1272-1278.

Ren, J. and 8 others. 1995. Glaciological studies on Nelson Island, South Shetland Islands, Antarctica. J. Glaciol., 41(138), 408-412.

Servicio Geográfico del Ejército (SGE). 1991. Cartografía Antártica Española: Islas Livingston y Decepción. Escala 1:100000. Madrid, Servicio Geográfico del Ejército.

Simões, J.C. and U.F. Bremer. 1995. Investigation of King George Island ice cover using ERS-1 SAR and SPOT imagery. Rev. SELPER, 11(1-2), Special Publication, 56-60.

Simões, J.C., U.F. Bremer, F.E. Aquino and F.A. Ferron. 1999. Morphology and variations of glacial drainage basins in the King George Island ice field, Antarctica. Ann. Glaciol., 29, 220-224.

Travassos, J.M. and J.C. Simões. 2004. High-resolution radar mapping of internal layers of a subpolar ice cap, King George Island, Antarctica. Pesqui. Antárt. Brasil., 4, 57-65.

United Kingdom: Directorate of Overseas Surveys (DOS). 1968. British Antarctic Territory, South Shetland Isle, 1:200000. Sheets W62 58 and W62 60. Tolworth, Directorate of Overseas Surveys.

Vasilenko, E.V., V.A. Sokolov, Y. Macheret, A.F. Glazovsky, M.L. Cuadrado and F.J. Navarro. 2002. A digital recording system for radioglaciological studies. Bull. R. Soc. N. Z., 35, 611-618.

Vinogradov, O.N. and T.V. Psareva. 1990. Sovremennoye oledeneniye priantarkticheskikh ostrovov [Present-day glaciation of subAntarctic islands]. Mater. Glyatsiol. Issled. 68, 117-126. [In Russian with English summary.]

Ximenis, L. 2001. Dinàmica de la glacera Johnsons (Livingston, Shetland del Sud, Antàrtida). (PhD thesis, Universitat de Barcelona.) 